Frank誘導心電図に拈ける高周波成分の臨床的評価

\author{
杏林大学医学部第二内科（指導 石川恭三教授） \\ 四倉 正之
}

CLINICAL EVALUATION OF HIGH FREQUENCY COMPONENTS

ON THE QRS COMPLEXES IN ORTHOGONAL ELECTROCARDIOGRAM BY FRANK SYSTEM

Masayuki YOTSUKURA, MD
The Second Department of Internal Medicine, Kyorin University, School of Medicine, Tokyo

\begin{abstract}
概要 Frank誘導心電図のQRS波上に認められる高周波成分 (high frequency components:

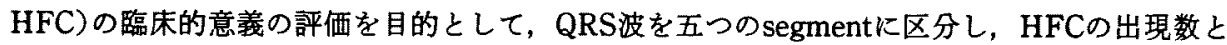
出現部位について検討を加えた. 正常群265例, 心筇梗塞群151例, 左室肥大群60例, 右室肥大 群44例, 右脚ブロック群47例, 左脚ブロック群14例, WPW群18例, およびpoor R wave progression群65例を対象とした。疾患により HFCの出現部位はをれぞれ異なつており，心筇梗塞群で はQRS波の初期部分に，心肥大群では中央部に，脚ブロック群では伝導遅延の見られる部位に HFCが增加していた。 心筋梗塞群では梗塞部位の違いにより HFCの出現部位が異なり, 前壁中 隔梗塞ではX, Y, Zの 3 誘導の $\mathrm{R}$ upstrokeと R peakに，下壁梗塞ではQy, Qzに，後壁梗塞では Ry upstroke, Ry peak, QzkHFCが増加していた。 心筋梗塞群の27例における発症後 1，3， 12力月の释時的変化ではHFCの数に大きな変化は認められなかつた。 poor R wave progression群のらち，正常例と前壁中隔梗塞例とはHFCの数と出現部位により， sensitivity $85.0 \%$, specificity $76.7 \%$, predictive accuracy $70.8 \%$ の高い精度で鑑別することができた，HFCは 一般にあまり顧みられていないが，出現数と出現部位を詳細に検討することにより，臨床的に 有用な情報が得られると考えられた。
\end{abstract}

\section{粕 菜}

心電図のQRS波上には，通常の熱ペン式心電計 では記録することのできない高周波成分（high frequency components：HFC) が存在すること は50年以上前から指摘されている122) この HFC は, オシログラフなどの周波数特性の高い機械を 用いることにより notchやslurとして記録される。

しかし，HFCの臨床的応用についての報告は少 なく，なたFCの記録が可能な機器の普及が不十 分であつたこともあり，臨床的に注汪とんど顧み られてこなかつた. 近年, 高性能の記録機器の普

[昭和59年12月 10 日受稿]
及が進み, HFCの記録が容易となり, HFCの詳細 な臨床的評価が可能となつてきた。

そこで本研究では, 修正直交軸誘導心電図 (corrected orthogonal lead electrocardiogram) に拉 けるHFCの臨床的意美の評価を, 正常人括よび 種々の心疾患患者について, 主として次の 3 点に 焦点を合わせて検討した。

（1） $\mathrm{HFC}$ QRSS波上の出現部位と各種心疾患 の相関性について。

（2）心筋梗塞例に拈けるHFCの経時的変化と, 心機能との関連性について。

(3) Poor R wave progression (PRWP) を呈 する症例に打けるHFCの鑑別能について。 
対触および方法

対象は(A)正常例括よび各種心疾患例と，

PRWP例の二つに大別した。

（A）正常例および各種心疾患例は，正常群，心 筋梗塞群, 左室肥大群, 右室肥大群, 右脚ブロッ ク群, 左脚ブロック群, WPW群の 7 群とし, 各群 を下記のように定めた。

（1）正常群 (265例；男150例，女115例；年令： 平均31.7才，2才～68才）：高血纴，虚血性心疾 患, 弁膜症, 不整脈などの循環器疾患, および糖 疗病，負血，甲状腺機能異常などの心血管采に影 響を及注すと考えられる疾患を有せず，さらに理 学的所見および胸部X線写真で異常を認めないる のを正常群とした。

（2）心筋梗塞群 (151例；男120例，女 31 例；年 令：平均63.2才，34才８9才）：臨床経過，血清 酵素値，心電図などより，心筋梗塞の既往が明ら かなるのを心筋梗塞群とした．分析に用いた修正 直交軸誘導心電図は発症後 1 力月から 6 力月の間 に記録されたものである。梗塞部位は，異常 $\mathrm{Q}$ 波 ならびにST-T変化の存在部位により次の 8 群に 細分しだ!.

（a）前壁中隔梗塞群（52例；男40例，女12例； 年令：平均64.3才，34才一 89才）

（b）下壁梗塞群（43例；男34例, 女 9 例；年 令：平均 64.1 才， 40 才一 82 才)

（c）後壁梗塞群 ( 8 例；男 7 例, 女 1 例；年令： 平均 61.2 才, 38 才一 78 才)

（d）側壁梗塞群（4例；男 4 例, 女 0 例；年 令: 平均 56.3 才, 49 才 64 才)

（e）前壁中隔十下壁梗塞群（16例；男12例，女 4 例：年令：平均 70.2 才, 37 才 25 才)

（f）前壁中隔十側壁梗塞群 (16例：男16例, 女 0 例；年令：平均 60.4 才，40才 21 才)

（g）下壁十後壁梗塞群（7例；男 5 例，女 2 例；年令：平均 60.9 才, 53 才 20 才)

(h) 心内膜下梗塞群 ( 5 例；男 2 例，女 3 例： 年令: 平均 66.2 才, 57 才 72 才)

（3）左室肥大群(60例：男36例, 女 24 例；年令： 平均55.9才, 19才〜82才)：心エコ一図に拈いて左 室後壁の壁厚が15mmを超えるるのを左室肥大群 とした。疾患のうちわけは，弁膜症30例（大動脈 弁閉鎖不全症17例，僧帽弁閉鎖不全症 4 例，僧帽 升閉鎖不全兼狭窄症 3 例，大動脈弁狭窄症 2 例， 連合升膜症 4 例)，心筋症16例，高血圧症14例であ る.

（4）右室肥大群(44例, 男19例, 女25例；年令：平

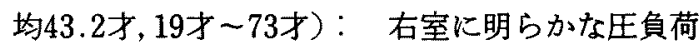
ないしは容量負荷が存在することが, 心臓カテーテ ル検査で確認された症例を右室肥大群とした。疾 患の5ちわけは，弁膜症28例(僧帽弁㹨窄症16例， 僧帽弁閉鎖不全兼狭窄症 9 例，連合弁膜症 3 例)， 先天性心疾患 9 例(ASD 4 例, VSD 3 例, Fallot 四徵症 2 例)，肺疾患 4 例，心筋症 3 例である。

（5）右脚ブロック群（47例，男24例，女23例： 年令：平均 55.7 才, 15才 24 才)：幅広いS 波を X抢よびZ誘導に認め, QRS loop上にterminal delayを有するものを右脚ブロック群とした4). QRS時間が0.12秒以上のものを完全右脚ブロッ ク群 (31例)，0.12秒末満のものを不完全右脚ブ ロック群（16例）とした．ただし先天性心疾患を 有するものは除外した。

（6）左脚ブロック群（14例，男10例，女 4 例： 年令：平均69.3才，9才７9才)：QRS時間 が0.12秒以上で， $Z$ 誘導に括いて $\mathrm{Q} / \mathrm{R}$ 比が0.10以 下であり，QRS loopの中間部にdelayを有するも のを左脚ブロック群としだ).

（7）WPW群(18例，男10例，女 8 例；年令：平 均43.6才，8才ー71才)：PQ時が短縮しデルタ 波を有するものをWPW群とした.

ただし，心筋梗塞以外の群からは心筋梗塞の既 往のある症例は除外し，また脚ブロックおよび WPW群以外の群からは伀導障害を有する症例は 除外した。

(B) 標準12誘導心電図でV1からV3においてrS 型を呈し，かつ $\mathrm{R}$ 波高が0.3mV以下のものを PRWP群とし，下記の 3 群に分類した。

(1) PRWP正常群 (30例，男 7 例，女23例；年 令：平均48.4才，20才一74才）:PRWPを呈す るが臨床診断で心筋梗塞およびその他の心疾患を 
有していない正常例をPRWP正常群とした.

（2）PRWP前壁中隔梗塞群 (20例，男19例，女 1 例; 年令: 平均 62.2 才，51才７9才）: PRWP を呈し，かつ明らかな前壁中隔梗塞の既往のある ものをPRWP前壁中隔梗塞群とした。

(3) PRWP左室肥大群 (15例, 男8例, 女7例；年 令：平均65.3才，44才〜81才)：PRWPを呈す るが心筋梗塞の既往がなく，かつ前述の左室肥大 の基準を满たすものをPRWP左室肥大群とした。 心電図はFrank誘導法 ${ }^{5}$ により記録したX, Y, Z の 3 誘導のスカラー心電図を用いた。記録機器は, フクダ電子製VA3Dベクトル心電計にSiemens製 Mingograf 800を接続したものを用いた，VA3D ベクトル心電計の周波数特性は $0.05 \mathrm{~Hz}$ から500 Hzであり，Mingograf 800の周波数特性は 0 から $1250 \mathrm{~Hz}$ である，心電図は $1 \mathrm{mV}$ を $30 \mathrm{~mm}$ とし，紙送 り速度は毎秒 $250 \mathrm{~mm} て ゙$ 記録した。

QRS 波上に記録された周波数 $125 \mathrm{~Hz}$ 以上の notchをHFCをし, 肉眼で計測した。 notchは, Flowersら ${ }^{6}$ の提唱した定義に従がい，QRS波の基 本波形から離脱し，さらにその方向が基本波形と は反対の方向に向かつているものとした。な报， slur, 寸なわちQRS波の基本波形から離脱するが， その方向が基本波形と同方向のものは, 本研究の 分析対象とはしなかつた。図 1 にHFCの実例を示 した。また，筋電図および外部からのノイズと HFCを区別するために，4心拍以上にわたつて QRS波上の同一部位に記録されたnotchのみを HFCと同定した。

QRS波は図 1 に示したように, Q, R upstroke, $\mathrm{R}$ peak, $\mathrm{R}$ downstroke, Sの五つのsegmentに分 割した。 R波上行脚の下 $2 / 3 を R$ upstrokeとし， R 波下行脚の下 $2 / 3 を \mathrm{R}$ downstrokeとし， R 波の頂 上部 $1 / 3 を \mathrm{R}$ peakとした。

各群についてX, Y, Zの 3 誘導のHFCの総数, 誘導別のHFC数, segment別のHFC数を計測し, 正常群との対比を行なつた. 正常群については, さらに年令別执よび性別の検討を加えた。をた心 筋梗塞群の5ち27例は, 発症後 1 力月, 3 力月拉 よび12カ月の 3 回にわたり，心電図の記録とRI

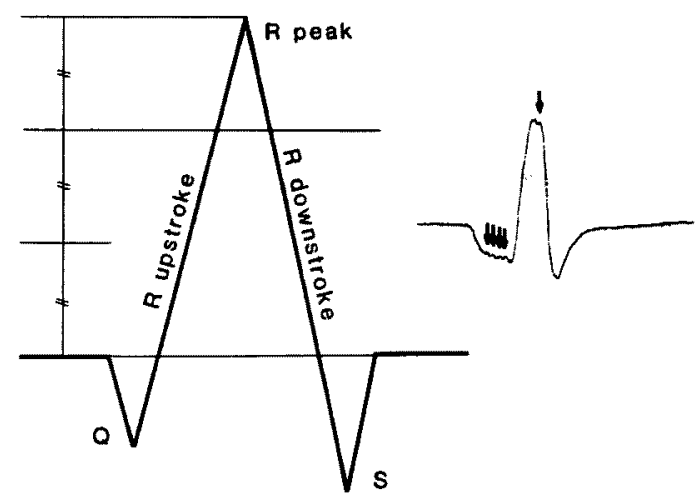

図 1. Segment分割法とHFCの実例.

QRS波をQ, R upstroke, R peak, R downstroke, $\mathrm{S}$ の五つのsegmentに分割した，矢印でHFCを示した。 Qに4 個, R peakに1 個のHFCがみられる.

angiographyを施行し，HFCの数の経時的变化, およびHFCの数とRI angiographyによるleft ventricular ejection fraction (LVEF) との関連 性について検討した，PRWP群では，QRS波上の segment別の分析を行ない, HFCによる正常例, 前壁中隔梗塞例扣よび左室肥大例の鑑別を試み た。

\section{結 果}

(I)各群におけるHFCの出現数と出現部位 表 1 および図 2，3に各群のQRS波上の segment別のHFCの数を示した。

(1) 正常群

$\mathrm{HFC}$ の 3 誘導の総数は $7.0 \pm 3.5$ (平均土標準偏 差)であり，誘導別では， $Z$ 誘導, $Y$ 誘導, $X$ 誘 導の順に多く出現していた（ $Z$ 誘導とY誘導では $\mathrm{p}<0.01, \mathrm{Y}$ 誘導とX誘導では $\mathrm{p}<0.001$ 有意差 を示した). segment別では，Rx peak（X誘導に 扣けるR peak, 以下同様の略記法を用いる)， Sx, Ry peak, Qz, Rz peakに多〈出現していた，表 2 に示したよらに, HFCの出現頻度には明らかな性 差は認められなかつた。年令别では20才台の男性 に扣いて他の年代より有意 $(\mathrm{p}<0.05)$ に増加して いたが，他の年代間には有意差は認められなかっ た.

（2）心筋梗塞群

心筋梗塞の各群の 3 誘導のHFCの総数は正常 


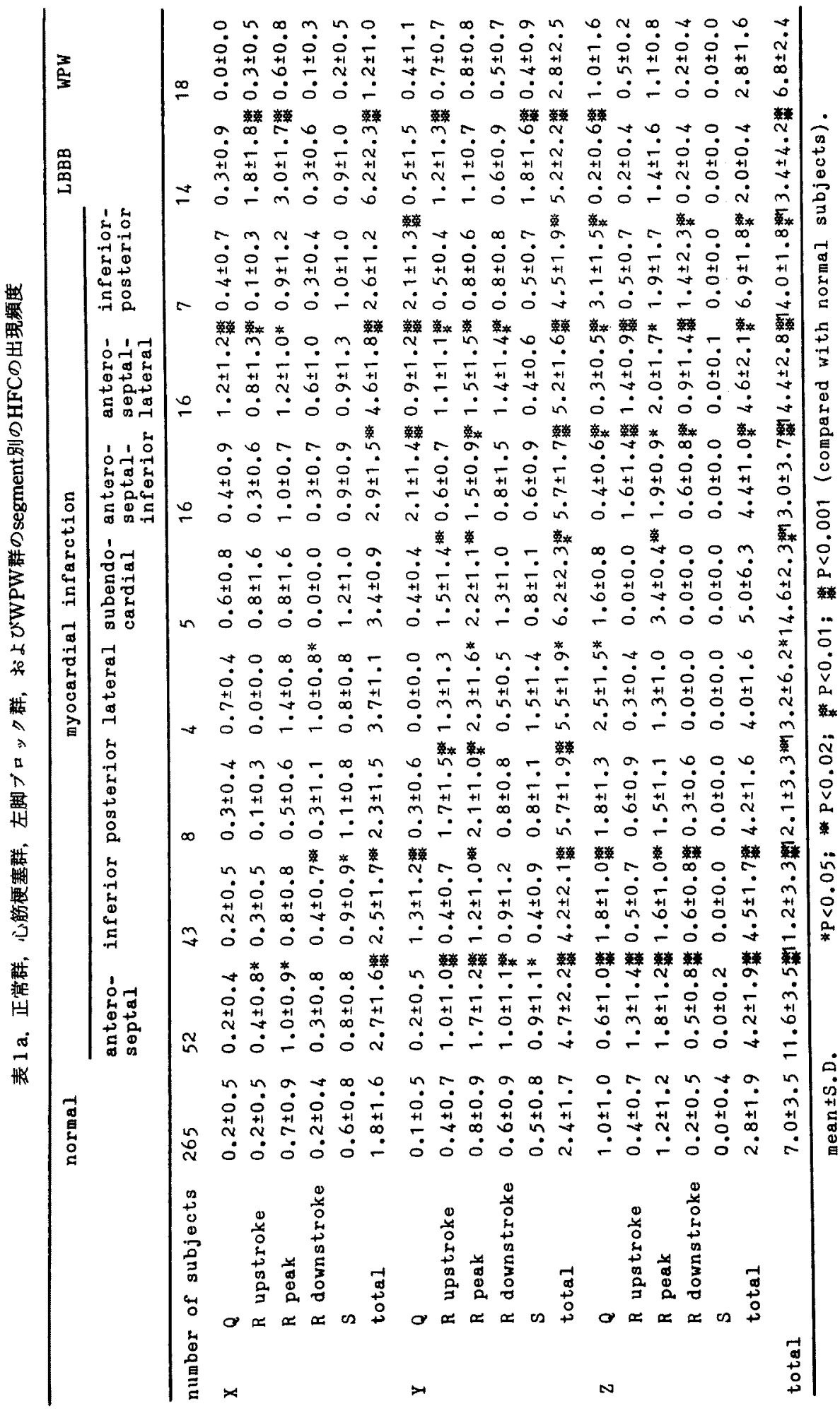




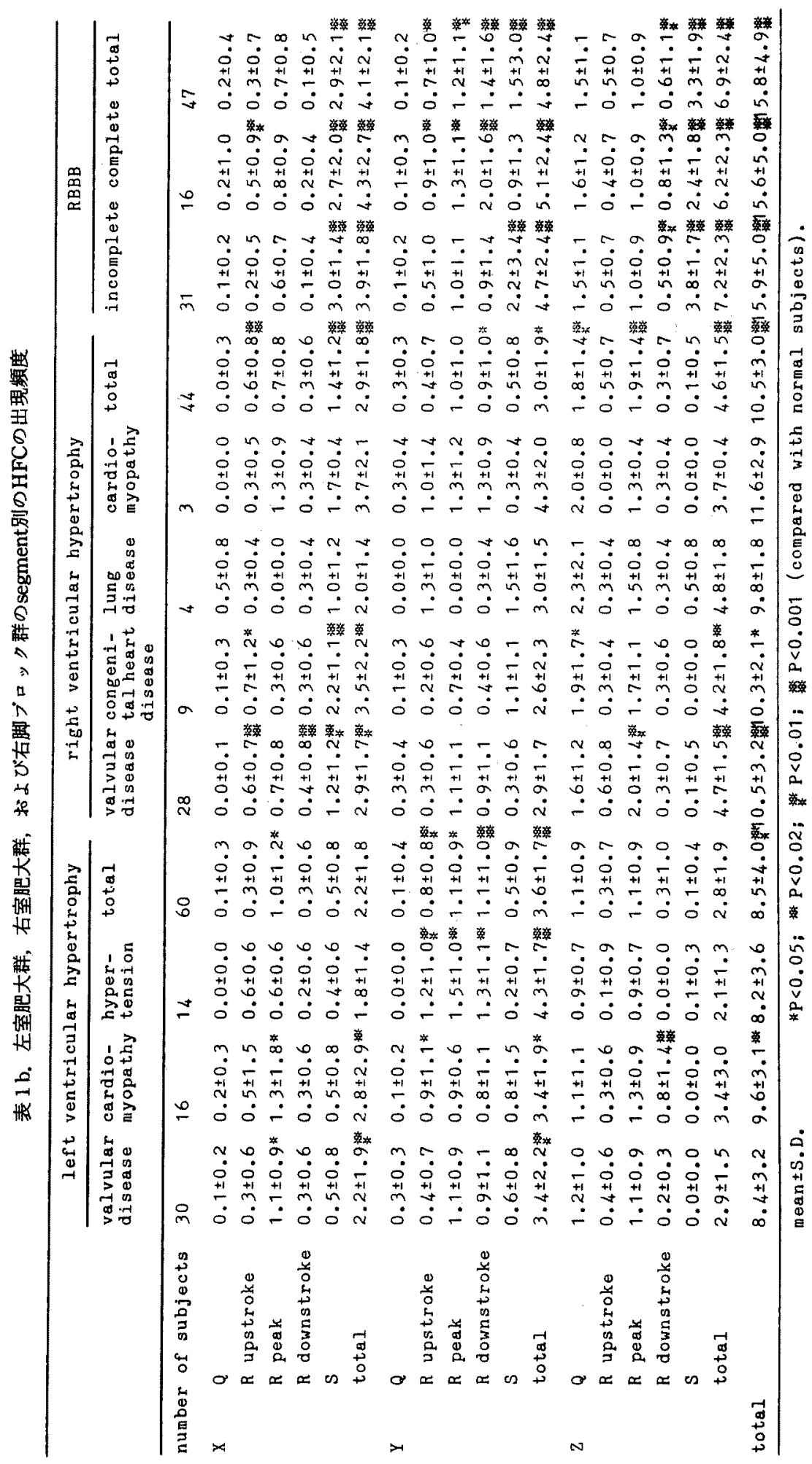




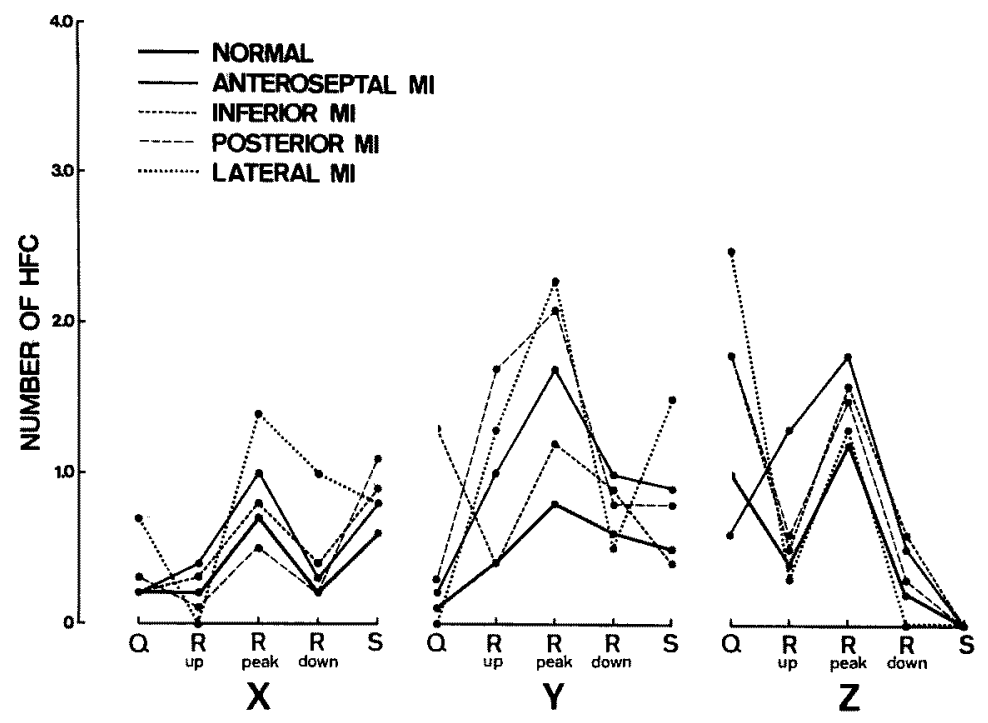

図 2. 正常群と心筋梗塞の各群のsegment别のHFC数。

前壁中隔梗塞群では 3 誘導のR upstrokeおよびR peakで, 下壁梗塞群ではQy，Qz で, 後壁梗塞群ではRy upstroke, Ry peak, Qzで，侧壁梗塞群ではQx, Rx peak, Rx downstroke, Ry upstroke, Ry peak, Sy, Qzで正常群と比較してHFCが增加してい た.

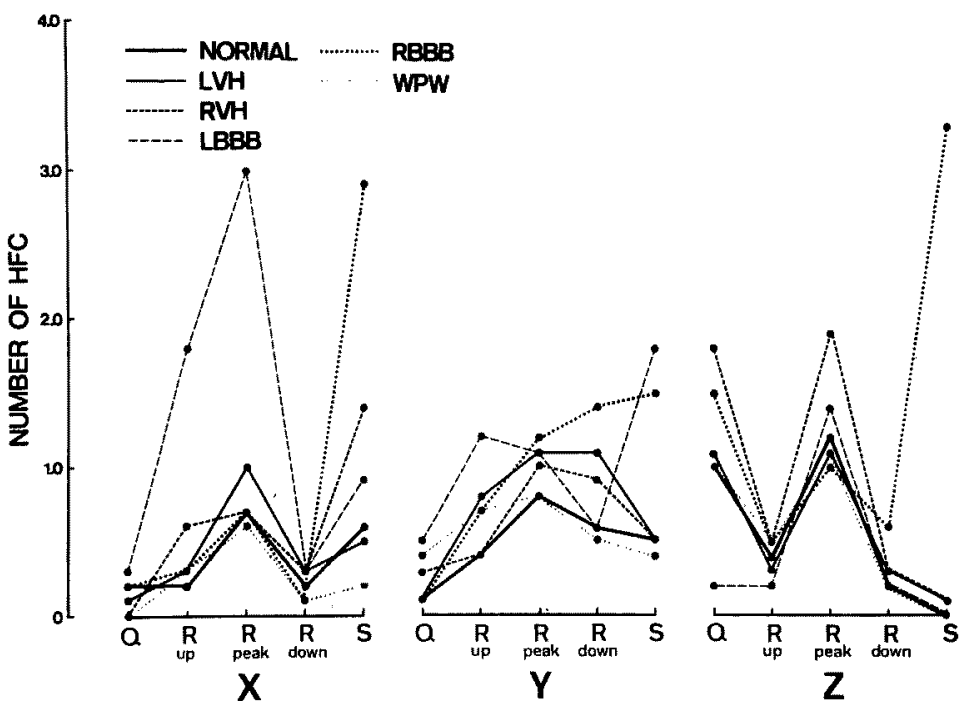

図 3、心肥大群, 脚ブロック群执よびWW群のsegment別のHFC数。

左室肥大群ではRx peak, Ry upstroke, Ry peak, Ry downstrokeで, 右室肥大群 ではRx upstroke, $\mathrm{Sx}, \mathrm{Qz}, \mathrm{Rz}$ peakで, 左脚ブロック群ではRx upstroke, Rx peak, Ry upstroke, Syで，右脚ブロック群では 3 誘導のS波で正常群と比較してHFCが增 加していた，WPW群ではHFCの增加は認められなかつた。 
表 2．正常群の性別括よび年令別にみたHFCの出現頻度

\begin{tabular}{|c|c|c|c|c|c|c|c|c|c|}
\hline age & & $0-9$ & 10.19 & $20-29$ & $30-39$ & $40-49$ & $50-59$ & $60-69$ & 0.69 \\
\hline \multicolumn{10}{|l|}{ male } \\
\hline number of subj & $\operatorname{cts}$ & 12 & 17 & 54 & 32 & 18 & 13 & 4 & 150 \\
\hline \multirow[t]{3}{*}{ number } & $x$ & $1.7 \pm 1.7$ & $2.1 \pm 1.7$ & $1.7 \pm 1.8$ & $1.4 \pm 1.2$ & $1.9 \pm 1.4$ & $1.5 \pm 1.4$ & $1.3 \pm 1.9$ & $1.7 \pm 1.6$ \\
\hline & $\mathrm{Y}$ & $2.1 \pm 1.2$ & $2.5 \pm 1.4$ & $3.0 \pm 2.0$ & $2.1 \pm 1.6$ & $1.6 \pm 1.3$ & $2.6 \pm 1.4$ & $3.3 \pm 1.9$ & $2.5 \pm 1.8$ \\
\hline & $\mathbf{Z}$ & $2.8 \pm 3.2$ & $2.9 \pm 1.6$ & $3.6 \pm 2.0$ & $2.8 \pm 1.7$ & $2.7 \pm 1.5$ & $2.1 \pm 1.6$ & $1.5 \pm 0.6$ & $3.0 \pm 1.9$ \\
\hline & $\operatorname{tal}$ & $6.6 \pm 3.2$ & $7.5 \pm 3.2$ & $8.4 \div 6.4$ & $6.4 \pm 3.8$ & $6.2 \pm 2.1$ & $6.2 \pm 1.4$ & $6.0 \pm 3.4$ & $7.2 \pm 3.6$ \\
\hline \multicolumn{10}{|l|}{ feme 3} \\
\hline number of subj & $\operatorname{ctg}$ & 9 & 20 & 21 & 16 & 27 & 15 & 7 & 115 \\
\hline number of HFC & $x$ & $1.6 \pm 1.2$ & $2.6 \pm 1.9$ & $1.8 \pm 1.2$ & $1.1 \pm 1.2$ & $2.0 \pm 1.4$ & $2.1 \pm 3.1$ & $1.3 \pm 1.1$ & $1.9 \pm 1.8$ \\
\hline \multirow{2}{*}{ number } & $Y$ & $1.7 \pm 2.2$ & $2.2 \pm 1.6$ & $2.6 \pm 2.4$ & $1.9 \pm 1.9$ & $2.0 \pm 1.2$ & $2.6 \pm 1.8$ & $3.3 \pm 1.7$ & $2.3 \pm 1.8$ \\
\hline & $z$ & $2.2 \pm 2.0$ & $3.3 \pm 2.2$ & $3.2 \pm 2.6$ & $2.5 \pm 1.3$ & $2.2 \pm 2.1$ & $2.3 \pm 1.2$ & $2.9 \pm 1.5$ & $2.6 \pm 2.0$ \\
\hline & $\mathrm{tal}$ & $5.4 \pm 4.5$ & $8.1 \pm 3.0$ & $7.5 \pm 4.1$ & $5.6 \pm 2.5$ & $6.2 \pm 3.2$ & $6.9 \pm 3.0$ & $7.4 \pm 2.5$ & $6.8 \pm 3.4$ \\
\hline \multicolumn{10}{|l|}{ total } \\
\hline number of subj & tes & 21 & 37 & 75 & 48 & 45 & 28 & 11 & 265 \\
\hline \multirow[t]{4}{*}{ number of HFC } & $\mathrm{x}$ & $1.6 \pm 1.5$ & $2.4 \pm 1.8$ & $1.8 \pm 1.7$ & $1.3 \pm 1.2$ & $2.0 \pm 1.4$ & $1.8 \pm 2.4$ & $1.3 \pm 1.4$ & $1.8 \pm \uparrow .6$ \\
\hline & $\mathbf{Y}$ & $1.9 \pm 1.7$ & $2.4 \pm 1.5$ & $2.9 \pm 2.1$ & $2.1 \pm 1.7$ & $1.8 \pm 1.2$ & $2.6 \pm 1.6$ & $3.3 \pm 1.7$ & $2.4 \pm 1.7$ \\
\hline & $z$ & $2.6 \pm 2.2$ & $3.1 \pm 1.9$ & $3.5 \pm 2.2$ & $2.7 \pm 1.6$ & $2.4 \pm 1.9$ & $2.1 \pm 1.4$ & $2.4 \pm 1.4$ & $2.8 \pm 1.9$ \\
\hline & al & $6.1 \pm 3.8$ & $7.8 \pm 3.1$ & $8.1 \pm 4.1$ & $6.1 \pm 3.4$ & $6.2 \pm 2.8$ & $6.6 \pm 2.8$ & $6.9 \pm 2.8$ & $7.0 \pm 3.5$ \\
\hline
\end{tabular}

群より有意 $(\mathrm{p}<0.05$ 以上) に多く, また心筋梗塞 の各群の間では, 前壁中隔十側壁梗塞群が, 前壁 中隔梗塞群贴よび下壁梗塞群より有意 $(\mathrm{p}<0.02)$ に多く認められた。他の心筋梗塞の各群の間には 有意差は認められなかつた。誘導別でのHFCの数 は，各群とすべての誘導で正常群と比較して増 加してお゙り，特にY誘導での増加が著明であつた。 segment別では，HFCの增加する segmentは梗塞 部位により異なつていた，前壁中隔梗塞群では正 常群と比較して 3 誘導のR upstroke括よびR peakで, 下壁梗塞群ではQy,Qzで，後壁梗塞群で はRy upstroke, Ry peak，Qzでそれぞれ著明に増 加していた。 また，症例数は少ないが，側壁梗塞 群ではQx, Rx peak, Rx downstroke, Ry upstroke, Ry peak, Sy, Qzk，心内膜下梗塞群では $\mathrm{Rx}$ upstroke, Sx, Ry upstroke, Ry peak, Ry downstroke, $\mathrm{Rz}$ peakに増加する傾向が認められ た。前壁中隔十下壁梗塞群ではQy, Ry peak, Rz upstroke, $\mathrm{Rz}$ downstrokeで増加し，前壁中隔梗 塞群と下壁梗塞群の両方の特徵を有していた。前 壁中隔十側壁梗塞群ではQx, Rx upstroke, Qy，おo よびY, Z誘導の R upstroke, R peak, R downstrokeで増加し，前壁中隔梗塞群と側壁梗塞群の両方 の特接を有していた。下壁十後壁梗塞群ではQy， Qzに多く認められ，下壁梗塞群と同じ傾向を示し ていた。
発症後 1 力月， 3 力月および12力月における HFCの数の変化は多くもと 3 個程度であり大き な变動は認められなかつた。また，LVEFとHFC 数との相関関係は認められなかつた。

(3) 左室肥大群

3 誘導の HFCの総数は8.5土4.0で正常群より 有意に増加していた。誘導別ではY誘導のみが正 常群より有意に増加していた。 segment別ではRx peak, Ry upstroke, Ry peak, Ry downstrokek 増加していた．左室肥大の原因となつた疾患によ るHFCの数揖よび出現部位に有意差は認められ なかつた。

\section{(4) 右室肥大群}

3 誘導のHFCの総数は10.5 3 .0で正常群より 有意に増加しており，誘導別でも 3 誘導とも正常 群より有意に増加していた。 segment別では Rx upstroke, $\mathrm{Sx}, \mathrm{Qz}, \mathrm{Rz}$ peakに增加していた，右室 肥大の基礎疾患によるHFCの数および出現部位 に有意差は認められなかつた。

\section{（5）右脚ブロック群}

3 誘導のHFCの総数は15.8 44.9 で正常群より 有意に多く，誘導別では 3 誘導とも正常群より有 意に多く出現していた. segment別ではSx， Ry upstroke, Ry peak, Ry downstroke, Sy, Rz downstroke, Szに增加して扣り，3誘導とも $\mathrm{S}$ 波 に多く出現していることが特徽的であつた。また 
完全右脚ブロック群と不完全右脚ブロック群の間 にはHFCの数に有意差は認めなかつた。

(6) 左脚ブロック群

3 誘導のHFCの総数は13.4 4 .2 2゙正常群より 有意に多く, 誘導別ではX扣よびY誘導で正常群 より有意に多く出現していた。 segment別ではRx upstroke, Rx peak, Ry upstroke, Syに增加して いた.

(7) WPW 群

3 誘導のHFCの総数, 誘導別括よびsegment別 のHFCの数ともに正常群との間に有意差は認め られなかつた。

図 4 に各群の症例を示した。

\section{【II〕HFCによるPRWPの鑑別}

表 3 および図 5 , 図 6 にPRWP群の 3 誘導の HFCの総数拉よび誘導別, segment別のHFCの数 を示した. HFCの総数は, PRWP正常群では7.5士 2.4，PRWP前壁中隔梗塞群では12.4 23.1 , PRWP左室肥大群では9.2士4.5で, PRWP正常群

表 3.PRWP群のQRS波上のsegmemt別のHFCの出 現頻度

\begin{tabular}{|c|c|c|c|c|}
\hline & & $\begin{array}{l}\text { PRWP } \\
\text { nortmal }\end{array}$ & $\begin{array}{l}\text { PRWP } \\
\text { antero- } \\
\text { septal MI }\end{array}$ & $\begin{array}{l}\text { PRWP } \\
\text { LVH }\end{array}$ \\
\hline number & of subjects & 30 & 20 & 15 \\
\hline \multirow[t]{6}{*}{$\mathrm{X}$} & $Q$ & $0.1 \pm 0.4$ & $0.3 \pm 0.5$ & $0.3 \pm 0.7$ \\
\hline & R upstroke & $0.2 \pm 0.4$ & $0.4 \pm 0.6$ & $0.5 \pm 0.6$ \\
\hline & $\mathrm{R}$ peak & $0.8 \pm 0.9$ & $1.0 \pm 0.6$ & $0.9 \pm 0.6$ \\
\hline & R downstroke & $0.1 \pm 0.4$ & $0.2 \pm 0.5$ & $0.4 \pm 0.8$ \\
\hline & s & $0.7 \pm 1.2$ & $0.7 \pm 0.8$ & $0.9 \pm 1.0$ \\
\hline & total & $1.9 \pm 1.3$ & $2.5 \pm 1.4$ & $2.9 \pm 1.9 *$ \\
\hline \multirow[t]{6}{*}{$Y$} & $Q$ & $0.2 \pm 0.6$ & $0.2 \pm 0.5$ & $0.1 \pm 0.4$ \\
\hline & R upstroke & $0.6 \pm 0.6$ & $1.4 \pm 1.3$ & $0.9 \pm 1.1$ \\
\hline & R peak & $1.0 \pm 0.9$ & $2.2 \pm 1.7 \%$ & $1.1 \pm 0.8$ \\
\hline & A downstroke & $0.5 \pm 0.7$ & $1.6 \pm 1.5 *$ & $0.9 \pm 1.2$ \\
\hline & S & $0.4 \pm 0.6$ & $0.4 \pm 0.9$ & $0.2 \pm 0.4$ \\
\hline & total & $2.8 \pm 1.6$ & $5.7 \pm 2.5$ 政 & $3.2 \pm 1.9$ \\
\hline \multirow[t]{6}{*}{$z$} & $Q$ & $0.7 \pm 0.9$ & $0.6 \pm 0.6$ & $1.0 \pm 0.8$ \\
\hline & R upstroke & $0.4 \pm 0.6$ & $1.5 \pm 1.3$ & $0.5 \pm 0.9$ \\
\hline & $R$ peak & $1.5 \pm 0.9$ & $2.0 \pm 1.4$ & $1.5 \pm 1.2$ \\
\hline & $R$ downstroke & $0.3 \pm 0.8$ & $0.2 \pm 0.5$ & $0.1 \pm 0.3$ \\
\hline & $S$ & $0.0 \pm 0.0$ & $0.0 \pm 0.0$ & $0.0 \pm 0.0$ \\
\hline & total & $2.8 \pm 1.4$ & $4.3 \pm 1.7$ & $3.2 \pm 1.7$ \\
\hline total & & $7.5 \pm 2.4$ & $12.4 \pm 3.1 \%$ & $9.2 \pm 4.5$ \\
\hline
\end{tabular}
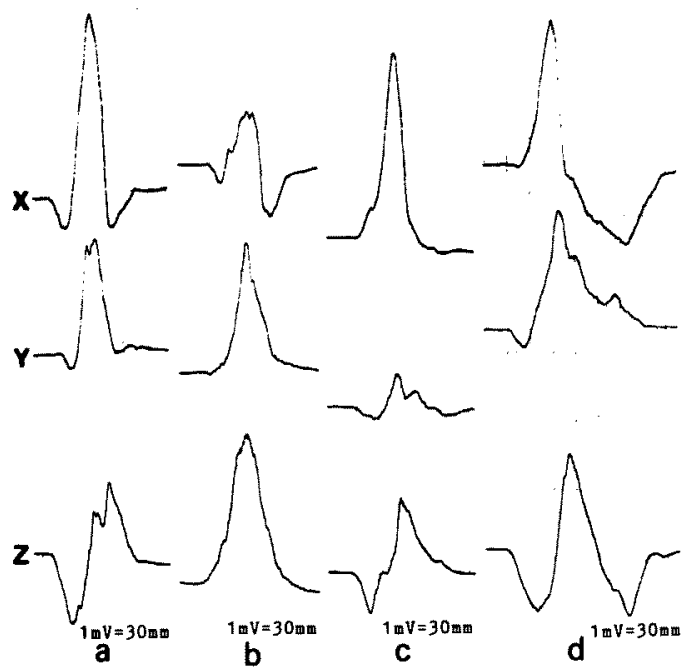

图 4. 症例，a：正常例(31才，男性)で7個のHFCを 認めた。 b：前壁中隔梗塞例(59才，男性)で18個のHFC を琶めた. c：下壁梗塞例(74才，男性)で11個のHFC を認めた，d：完全右脚ブロック例（56才，女性）で11 個のHFCを認めた。

とPRWP前壁中隔梗塞群, およびPRWP前壁中隔 梗塞群とPRWP左室肥大群との間に有意差 $(\mathrm{p}<$ $0.001, \mathrm{p}<0.05)$ を認めた．誘導別のHFCの数は， PRWP正常群とPRWP前壁中隔梗塞群では $\mathrm{Y}$ 誘 導 $(\mathrm{p}<0.001)$ 扎よび $Z$ 誘導 $(\mathrm{p}<0.01)$ で，PRWP 正常群之PRWP左室肥大群ではX誘導 $(\mathrm{p}<0.05)$ で,PRWP前壁中隔梗塞群とPRWP左室肥大群で はY誘導 $(\mathrm{p}<0.01)$ でそれぞれ有意差を認めた。 segment別のHFCはPRWP正常群とPRWP前壁 中隔梗塞群の間では，Ry upstroke, Ry peak, Ry downstroke, Rz upstrokeで, PRWP前壁中隔梗 塞群とPRWP左室肥大群との間ではRy peak, Rz upstrokeで有意差が認められた. PRWP正常群と PRWP左室肥大群の間には, segment別のHFCの 数に有意差は認めなからた。

図 7 に示したように, PRWP前壁中隔梗塞の診 断基準を，3 誘導のHFCの数の絵数が10個以上, とすると sensitivity $70.0 \%$, specificity $76.7 \%$, predictive accuracy $66.7 \%$ でPRWP正常群との 鑑別が可能であつた。ささらにsegment別の情報を 追加し，3 誘導の総数が10個以上またはRy down- 


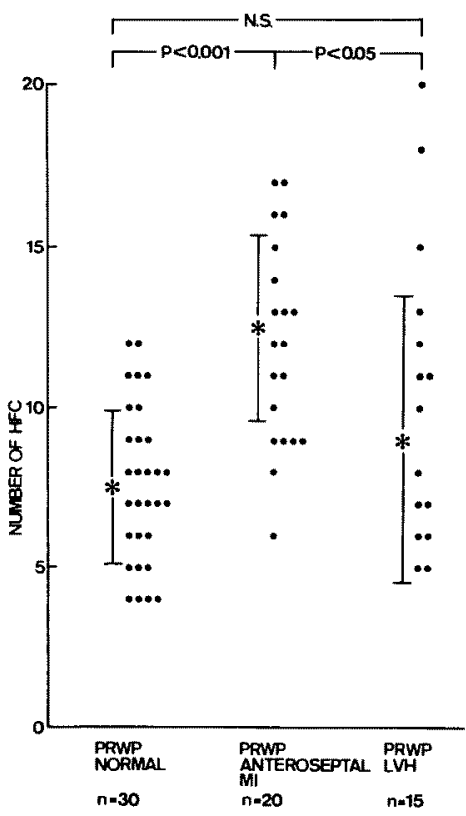

図 5.PRWP群のHFCの総数。 PRWP正常群とPRWP前壁中 隔梗塞群，扎よびPRWP前壁中隔 梗塞群とPRWP左室肥大群との 間でHFC数に有意差を認めた。
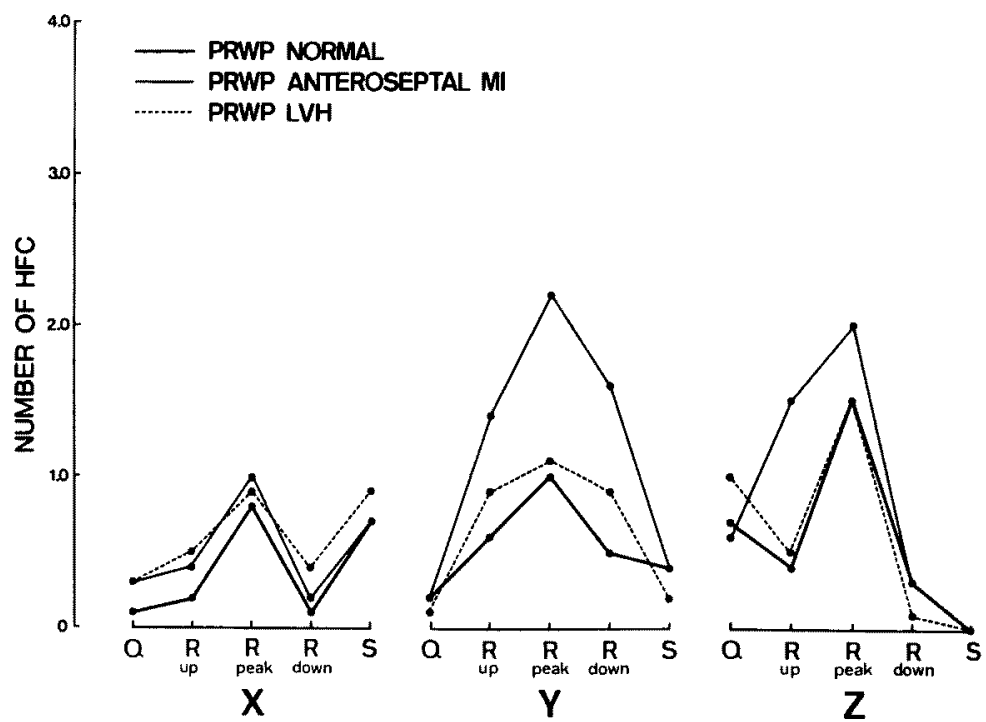

因 6.PRWPの各群のsegment別のHFC数. PRWP前壁中隔梗塞群では, Ry upstroke, Ry peak, Ry downstroke, Rz upstrokeでPRWP正常群より有意にHFCが増加していた. PRWP左 室肥大群はPRWP正常群との間にsegment別のHFC数の有意差を認め なかった。
strokeのHFCが 2 個以上,をPRWP前壁中隔梗塞 の診断基準とすると, sensitivity $85.0 \%$, specificity $76.7 \%$, predictive accuracy $70.8 \%$ と なり，診断精度が向上した，PRWP正常群と PRWP左室肥大群, 扣よびPRWP前壁中隔梗塞群 とPRWP左室肥大群との鑑別のための HFCによ る有用な診断基準の作成はできなかつた。

図 8 KPRWP正常群とPRWP前壁中隔梗塞群 の症例を示した。

\section{考 案}

心電図のHFCについては1950年代にReidら Groedelらがその存在を指摘している。しかし臨

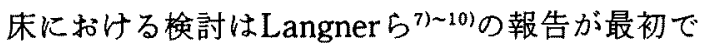
あり，彼らは陰極線オシログラフを用いて標準 12 誘導心電図のHFCを記録し，冠動脈疾患において HFCが增加することを報告した。またFlowers $5^{6) 1112)}$ は修正直交軸誘導心電図を用い，心肥大， 脚ブロックでもHFCが増加するとしており，

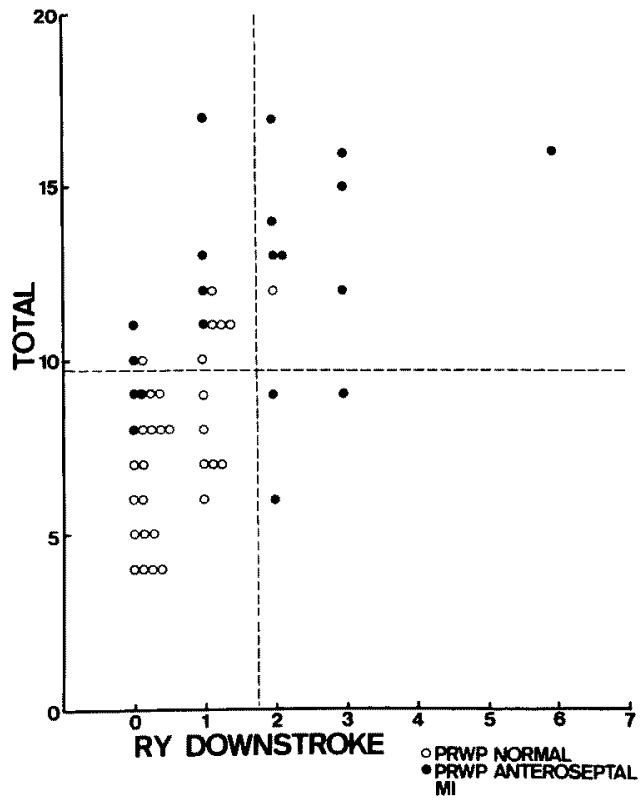

図 7、HFC数によるPRWP正常群とPRWP前壁中隔 梗塞群の鑑別のための診断基準

3 誘尊の総数が10個以上，またはR downstrokeで 2 個以上の症例をPRWP前壁中隔梗塞とした。 


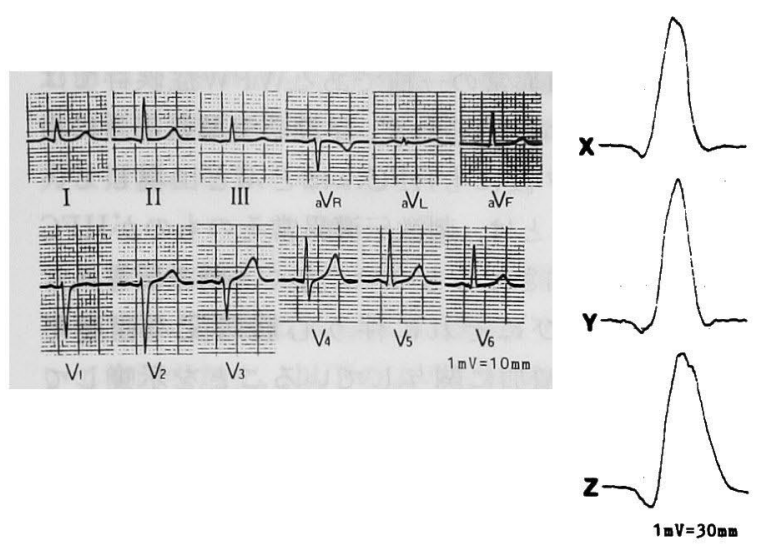

因 8 a. PRWP正常例

48才女性. 標準12誘導心電困ではPRWPを呈して拧 り前壁中隔梗塞を疑われたが，X，Y，Zの 3 誘導の HFCの総数は 5 個であり正常例と診断された。
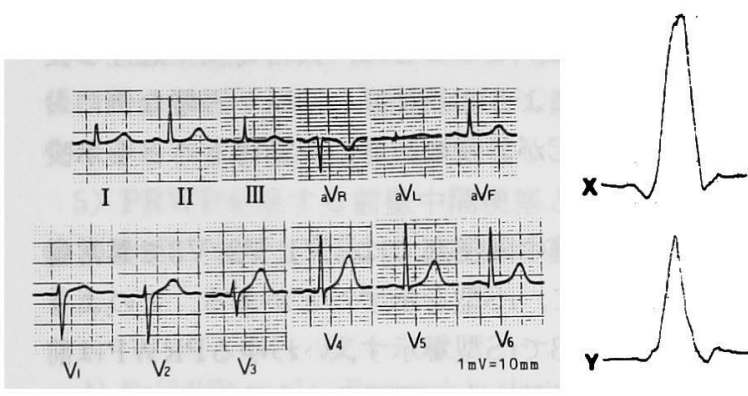

圀 8 b. PRWP前壁中隔梗塞例 46才男性. 標準12誘導心電图ではPRWPを呈してお り正常例との鑑別は困難であるが, X, Y, Zの 3 誘導の HFCの総数は14個であり前壁中隔梗塞と診断された。

Andersonら ${ }^{13)}$ は狭心症ではHFCは増加しないと している。ささらにウマチ熱で増加するとの報告

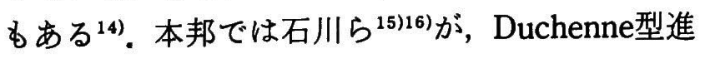
行性筋ジストロフィー症で, 病状の進展とともに HFCの数が増加することを報告している.

このように種々の心疾患に招いて HFCが増加 することは知られてきてはいるが, HFCの定義, 記録方法は研究者によつて異なつている。 また従 来の HFCの出現頻度の検討は誘導別の分析にと
どまつており，QRS波上のHFCの出現部位につい てはReynoldsら ${ }^{17)}$ の心筋症における検討がある のみである.そこで本研究ではQRS波を五つの segmentに分割し，各心疾患におけるQRS波上の HFCの出現部位を検討した。記録機器は, 過去に おいては主にオシログラフが用いられていたが, 本研究では, 一般に普及していること, 連続した 多数の心拍の記録が可能なことなどの理由により Mingograf 800を用いた。本研究において用いた

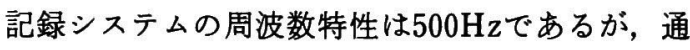
常用いられる最大の紙送り速度と考克られる毎秒 $250 \mathrm{~mm}$ でも $125 \mathrm{~Hz}$ の半周期は $1 \mathrm{~mm}$ であり, 肉眼に よる $\mathrm{HFC}$ 数の算定ではこの周波数特性で充分 と考兄られる。また，HFCは胸部誘導のような心 蔵に近い単極誘導に出現し易い。しかし，修正直 交軸誘導心電図に括いても HFCが多数出現

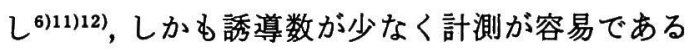
ことより本研究に扣いてはFrank誘導法を採用し た.

正常例のHFCの出現頻度については, 明らかな 性差は認められず, segment別では, Rx peak, Sx, Ry peak, $\mathrm{Qz}, \mathrm{Rz}$ peakに多く出現する傾向を示し た. 加令による動脈硬化を反映して，HFCの出現 頻度は高令者で増加するであろらと予測された が, 加令による増加は認められなかつた. Flowers $ら^{6}$ は高令者に多いとしており，Boyleら ${ }^{18}$ は本研 究と同じく，年令差はないとしている。報告者に より意見が異なるのは，記録方法やHFCの定義の 違いに起因すると考兄られる。

疾患群では 3 誘導のHFCの総数は, 右脚ブロッ クが最も多く, 以下. 左脚ブロック．心筋梗塞, 右室肥大, 左室肥大の順であつた. WPW症候群と 正常人との間ではHFC数に有意差を認めなかつ た。また左室肥大および右室肥大ともに，基礎疾 患の種類によるHFC数の有意差は認められなか つた。 心筋梗塞でも梗塞部位の違いによるHFC数 の差は認められなかつた。

誘導別では, Flowersら $5^{5}$ は, 前壁梗塞はX誘導 に, 後下壁梗塞はY誘導にHFCが多いとしている が, 本研究では, 前壁中隔梗塞, 下壁梗塞, およ 
び後壁梗塞ともにY扣よび $Z$ 誘導で増加してい た。また一般にlow voltageを呈する前壁中隔梗塞 扣よび下壁梗塞のY誘導, 左脚ブロックのX誘導, 右脚ブロックのZ誘導においてHFCが増加する 傾向が認められた。このことからlow voltageが HFCを増加させる一つの要因であることが推測 される。

Segment別では，疾患により各segmentの時間 が異なるため, 同じsegmentであつてる心周期に おける同一時期の比較とはならない。しかし， QRS波を何等分かしてみてる正確な同一時期の 比較のための区分は困難である，そこで本研究で は実用上容易なsegment分割法を用いた，疾患に より HFCが増加する segmentはそれぞれ異なつ ていた。前壁中隔梗塞では 3 誘導の R upstroke, $R$ peakに，下壁梗塞ではQy, QzK，後壁梗塞ではRy upstroke, Ry peak, Qzkそれぞれ増加傾向がみ られた。 また二つの異なる部位に梗塞を有する症 例では，それぞれの部位の梗塞に特徽的な所見の

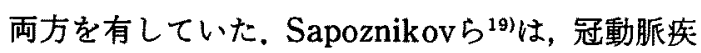
患では，本研究の対象としたHFCょり低周波の， いわば二峰性のQ波， R 波といえるようなnotch がQRS波の初期部分に出現すると報告している. 本研究でも心筋梗塞に括けるHFCの増加した segmentはQRS波の初期部分の segmentが主であ ク，125Hz以上のHFCについて bapoznikovら と同様の結果を得た. 左室肥大ではRx peak, Ry upstroke, Ry peak, Ry downstrokek，右室肥大 ではRx upstroke, Sx, Qz, Rz peakにそれぞれ HFCが多く認められた. Reynoldsら ${ }^{17)}$ は心筋症で はR波downstrokeのnotchが特徽的であるとして いるが, 本研究ではそのよらな特徵は認められず, R 波 downstroke以外の segmentでも HFCが増加 していた。心肥大でHFCの増加する segmentは QRS波の中央部の最大振幅を形成する部分にあ り，すなわち最大べクトル部分でHFCが増加して いた，右脚ブロックでは 3 誘導のS 波に，左脚ブ ロックではRx upstroke, Rx peak, Ry upstroke, SyにHFCの増加傾向が認められた。すなわち右脚 ブロックでは伝導遅延のみられる部分に, 左脚ブ
ロックではQRS波全体にHFCが増加していた。一 方, 刺激伝導異常の一種であるWPW症候群では HFCの増加は認められず, 早期心室興奮部分に相 当するデルタ波にもHFCはにとど出現してい ないこのことは，刺激伀導異常そのものがHFC の生成を増加させるものではなく, 刺激伝導異常 の程度ならびにそれに伴 5心筋病変の程度が HFCの生成増加に関与していることを示唆して いると考えられる。

心筋梗塞におけるHFC数とLVEFとの相関関 係は得られなからた：これは，正常人にもHFCが 存在するために，心筋梗塞自体に起因して出現し た HFCの正確な数の評価が不可能なこと，HFC と壁運動とは直接の関係がないこと、などの理由 によるものと考えられる。また心筇梗塞発症後の 経時的変化ではHFC数はほとんど变動せず, ほぼ 固定していた。このことは，異常 $\mathrm{Q}$ 波や冠性 $\mathrm{T}$ 波 などの消失により心筋梗塞の診断が困難な例にお いては，HFCが診断の一助になり得ることを示唆 している.

陳旧性前壁中隔梗塞では，V1, V2, V3で異常 $\mathrm{Q}$ 波が消失して, rS型を示すことがある。このよう にV1, V2, V3でrS型を示す, いわゆるPRWPは前 壁中隔梗塞以外にも, 正常例, 左室肥大, 右室肥 大に打いても認められ，鑑別診断上の大きな問題 の一つになつている. 前壁中隔梗塞と左室肥大の 鑑別診断は, QRS波高, 心房負荷, QRS平均電気 軸などを参考にすれば充分可能であるが，前壁中 隔梗塞と正常例との間の鑑別診断は従来より難問 とされてきた。そこで本研究に执いては，HFCの 情報を用いてPRWPを示す前壁中隔梗塞と正常 例についての鑑別診断を試み，前壁中隔梗塞と診 断する一つの基準を作成した。これは，X, Y,Zの 3 誘導のQRS波上に秘められるHFCの総数が 10 個以上，またはRy downstrokeでのHFCが 2 個以 上存在するものを前壁中隔梗塞と認定する基準で ある。このような単純な診断基準によつて，前壁 中隔梗塞によるPRWPを正常例にみられる PRWPから鑑別する精度は， sensitivity $85.0 \%$ ， specificity $76.7 \%$, predictive accuracy $70.8 \%$ で 
あつた．従来，心電図上のみからはきわめて難解 であつたPRWPを示す前壁中隔梗塞例と正常例 との鑑別診断に際して，この診断基準は一つの有 力な指針になると考学られる。

\section{結 論}

正常例, 各種心疾患例およびPRWP例の修正直 交軸誘導心電図にみられるQRS波上のHFCにつ いて検討を加え，以下のような結果が得られた。

1）正常例においてもHFCは存在した。 HFCの 出現頻度に性差はみられず，加令による增加も認 められなかつた。

2）心筋梗塞ではQRS波の初期部分に，心肥大 では中央部に，脚ブロックでは伝導遅延のみられ る部分において，HFCの增加が認められた。

3）心筋梗塞では梗塞部位により HFCの增加す るQRS波上のsegmentは異なつていた。

4）心筋梗塞におけるHFCはLVEFとは相関関 係は認められず，また発症後のHFC数の経時的変 化はみられず出現頻度はほぼ一定していた。

5）PRWPを呈する前壁中隔梗塞と正常例との 鑑别診断に有用なHFCによる診断基準を作成で きた。

\section{文献}

1) Reid WD, et al: Research in electrocardiography. Ann Intern Med $7: 369,1933$.

2) Groedel FM: Das ElectroKardiogramm. Theodore Steink off, Dresden and Leipzig, 1934.

3）石川恭三：フランク誘導法によるベクトル心電図 の読及方。医学書院，東京，1976.

4) Pipberger HV: Computer analysis of the electrocardiogram. In Computers in Biomedical Research. Vol 1, New York, Academic Press, 1965.

5) Frank E: An accurate, clinically practical system for spatial vectorcardiography. Circulation $13: 737,1956$.

6) Flowers NC: Location of the site of myocardial scarring in man by high-frequency components. Circulation 40:927, 1969.

7) Langner $\mathrm{PH}$ : The value of high fidelity electrocardiography using the cathode ray oscillograph and an expanded time scale. Cir. culation $5: 249,1952$.

8) Langner PH: Further studies in high fidelity electrocardiography: Myocardial infarction. Circulation $8: 905,1953$.

9) Langner $\mathrm{PH}$, et al: The relative significance of high-frequency and low-frequency notching in the electrocardiogram. Amer Heart J $71: 34$, 1966.

10) Langner $\mathrm{PH}$, et al: Wide band recording of the electrocardiogram and coronary heart disease. Amer Heart J $86: 308,1973$.

11) Flowers NC, et al: The anatomic basis for high-frequency components in the electrocardiogram. Circulation $39: 531,1969$.

12) Flowers NC and Horan LG: Diagnostic import of QRS notching in high-frequency electrocardiograms of living subjects with heart disease. Circulation $44: 605,1971$.

13) Anderson GJ and Blieden MF : The high frequency electrocardiogram in coronary artery disease. Amer Heart J $89: 349,1975$.

14) Holcroft JW and Liebman J: Notching of the QRS complex in high frequency electrocardiograms of normal children and in children with rheumatic fever. J Electrocardiol $3: 133,1970$.

15) Ishikawa $K$, et al : Orthogonal electrocardiographic study on progressive muscular dystrophy of the Duchenne type. J Electrocardiol 12 : $169,1979$.

16) Ishikawa $K$, et al: Sequential changes in high frequency notches on QRS complexes in progressive muscular dystrophy of the Duchenne type, A 3-year follow-up study. J Electrocardiol $15: 23,1982$.

17) Reynolds EW, et al: High frequency components in the electrocardiogram, A com. parative study of normals and patients with myocardial disease. Circulation 35 : 195, 1967.

18) Boyle $\mathrm{D}$, et al: High frequency electrocardiography in ischemic heart disease. Brit Heart J $28: 539,1966$.

19) Sapoznikov, et al: High fidelity ECG in the diagnosis of occult coronary artery disease : A study of patients with normal conventional ECG. J Electrocardiol 10: 137, 1977. 